\title{
1. Introduction: U.S. environmental policy research in uncertain times
}

\author{
David M. Konisky
}

The year 2020 marks several golden anniversaries in U.S. environmental policy. On July 9, 1970, President Richard Nixon signed an administrative reorganization plan that created the U.S. Environmental Protection Agency (EPA). Prior to that point, federal responsibilities for activities such as pollution control and chemicals regulation were limited in scope and scattered throughout different parts of the federal bureaucracy. The new EPA consolidated numerous existing federal authorities, including the National Air Pollution Control Administration, the Bureau of Water Hygiene, the Bureau of Solid Waste Management, and the Bureau on Radiological Health, from the Department of Health, Education, and Welfare, the Federal Water Quality Administration from the Department of the Interior (DOI), and three separate agencies responsible for pesticides control, including operations within the Department of Agriculture that had managed pesticide registrations (Williams 1993). This reorganization combined what had been disparate agencies, housed in different cabinet departments with varying organizational cultures, into a fledgling agency with a new shared mission to protect human health and the environment.

It is also the 50-year anniversary of several legislative achievements in the area of environmental protection and natural resource management. On January 1, 1970, President Nixon signed the National Environmental Policy Act (NEPA) into law. This statute, inspired by the work of an Indiana University political scientist, Lynton Caldwell, created the White House Council on Environmental Quality to coordinate federal policy on the environment, and required federal agencies to prospectively consider the environmental impacts of their major decisions (Wertz 2014). By requiring agencies to evaluate the environmental impacts of their actions, Congress signaled to the vast federal bureaucracy that agency decisions must at least be conscious of their environmental impacts.

Later the same year, Congress passed the landmark federal Clean Air Act (CAA) of 1970. This statute, which former EPA Administrator Gina McCarthy recently referred to as "one of the most successful public health laws ever enacted" (McCarthy and Burke 2017), systematically reshaped the U.S. approach to air pollution control. Responsibility for air quality before the 1970 CAA rested with state and local government authorities, most of which lacked the requisite institutional and financial capacity and/or the political will to meaningfully address increasingly severe air quality issues (Davies 1970). The CAA gave the federal government, and specifically the EPA, the authority to regulate air emissions from stationary (e.g., power plants, refineries, factories, etc.) and mobile (e.g., cars, trucks) sources of air pollution through a combination of prescriptive ambient and technology-based standards. Fifty years later, the EPA's use of the CAA still creates controversy, and regularly meets staunch opposition from many industry groups, but its programs have proven remarkably cost effective and durable (Carlson and Burtraw 2019). 


\section{Handbook of U.S. environmental policy}

NEPA and the CAA were just the beginning of a wave of new legislation enacted by Congress to address environmental problems. Soon to follow, among others, was the Clean Water Act (1972) (CWA), the Endangered Species Act (1973), the Safe Drinking Water Act (1974), the Resource Conservation and Recovery Act (1976), the National Forest Management Act (1976), the Toxic Substances Control Act (1976), and the Comprehensive Environmental Response, Compensation, and Liability Act (1980) (better known as Superfund). Collectively, this legislation reached deep into the American economy, affecting the behavior of firms operating industrial sources of pollution, municipalities managing wastewater and drinking water plants, private landowners whose properties contained endangered species, and many others. The wave of legislation also positioned the U.S. federal government as a central player in managing environmental quality. States, and to some degree local governments, have retained an important role too, especially with respect to implementing the national standards set by the EPA. But, the federal government, and with it national politics, moved to the forefront of U.S. environmental policy from this period forward. And, unmistakably, the legislation enacted during this "environmental decade" changed the course of policy in ways that have fundamentally shaped the politics, economics, and social aspects of environmental decision-making for the last half century.

What explains this intense period of environmental policymaking? First, the U.S. political system was responding to a growing swell of pressure from its citizens. Public awareness and concern about the environment had been intensifying for years, spurred on by the popular writing of authors such as Rachel Carson, growing scientific evidence that linked pollution to adverse effects on wildlife, people, and ecosystems, and focusing events such as the 1969 oil spill in Santa Barbara, which awakened more Americans to the risks of energy extraction. This escalating interest pushed environmental issues to the top of the government's agenda. The strength of public mobilization is perhaps best reflected by the estimated 20 million people that participated in the nation's first "Earth Day" on April 22, 1970.

Concerned citizens, many of whom became active participants in an emerging social movement, demanded action to regulate an increasingly chemical-intensive economy to protect human health, to intervene to prevent the extinction of iconic species such as the American bald eagle, and to better manage the nation's vast public land and natural resources. Feeling this pressure, but also seeking an electoral opportunity to capture the growing voter interest in the environment, Republican President Richard Nixon, Democratic Senator Edmund Muskie (Nixon's expected rival in the 1972 presidential election), and other politicians in Washington, DC responded with new laws and mandates that fundamentally transformed U.S. environmental policy.

The establishment of the EPA and the enactment of laws such as NEPA and the CAA marks the beginning of the modern era of environmental policy. Of course, U.S. environmental policy did not begin in 1970. At the federal level, government agencies have been actively involved in the management of natural resources on federal land for more than a century, and even longer if one considers the management of rivers and other waterways to facilitate interstate commerce and control floods (Doyle 2018). Among the tasks carried out by agencies within the Department of the Interior (e.g., the Bureau of Land Management, the U.S. Fish and Wildlife Service) and the Department of Agriculture (e.g., the U.S. Forest Service) are the management of rangelands, forests, and energy and mineral leases, the protection of national parks, and the management of various ecological and wildlife reserves. The scale of these tasks is immense. The U.S. federal government manages approximately 640 million 
acres of land, representing about 28 percent of the nation's entire land mass (Vincent, Hanson, and Argueta 2017). Most of this land is located in the western part of the country, where the decisions of federal agencies can have important consequences for local economies. Tension over federal management of western land and resources has periodically erupted, as reflected in the sagebrush rebellion of the 1970s and 1980s and the related wise-use movement of the 1980s and 1990s (Cawley 1993; Davis 2001), as well as, most recently, high-profile conflicts with western ranchers (Wang 2018).

There has long persisted a debate about the approach the federal government should take in its management of public land. The core friction is reflected in the historical clashes between the preservationist and conservationist factions of the environmental movement (Andrews 1999; Culhane 1981; Kline 2011). Preservationists, like Sierra Club founder John Muir, argued that some natural places were so valuable that the only sensible policy action was to set them aside from development into perpetuity. For their part, conservationists such as Gifford Pinchot, the first chief of the U.S. Forest Service, argued that natural resources should be used, but in a responsible (or in today's parlance, sustainable) manner. Both of these traditions are reflected in current U.S. practice. The national park system follows the preservationist approach of largely protecting special places from development, while the national forest system and lands managed by the Bureau of Land Management generally supports a more conservationist, multi-use approach.

In many respects, the basic contours of the debate between the preservationists and the conservationists have characterized public lands policy ever since. Current disputes, such as whether energy extraction should be permitted in places like the Arctic National Wildlife Refuge or whether presidents should set aside ecologically sensitive areas for protection as national monuments, typically engender arguments between those favoring a hands-off preservation approach and those that advocate for the use of these areas for resources extraction. Of course, many argue that such decisions are not an "either or" proposition, but typically the political disputes largely reduce the arguments to these terms. At the core of these disputes is a normative clash of values between broad political coalitions, which makes them difficult to resolve. Moreover, the orientation of government agencies at any given time depends on the political persuasion of those in elected office, meaning policy tends to ebb and flow.

The political, economic, and social dimensions of public lands management raise some unique issues, yet, in important ways, they share many basic characteristics with other current environmental policy disputes. With respect to most issues, the broad contours of the debate on environmental policy can be reduced to the question of how much, and to a lesser extent what type of, intervention in the economy is appropriate to achieve environmental protection goals. In most instances, one side (typically environmental organizations, Democrats) advocates for aggressive government action to address market failures, while the other side (usually business interests, Republicans) prefers only minimal intervention. And, because the two sides of this debate have become so embedded in broader American politics, they typically are unable to find much common ground. As a consequence, current U.S. environmental policy typically involves bitter, partisan and interest group politics, most often leading not just to disagreement, but policy gridlock at the national level.

Despite the contentious politics that have engulfed U.S. environmental policy for decades, government policy, combined with changes in private sector, public sector, and individual behavior, has undoubtedly produced some notable achievements. Air quality in most parts of the United States is undoubtedly improved. The first twenty years of the CAA alone generated 
an estimated \$22 trillion in benefits from outcomes such as avoided damages to human health, improvements in visibility, and reduced damage to agricultural crops, at just a fraction of the cost (an estimated $\$ 523$ billion) (U.S. EPA 1997). Among other significant accomplishments are the remediation of thousands of contaminated sites, the recovery of endangered species such as the bald eagle, the American alligator, and the gray wolf, the banning (at least for domestic use) of some harmful chemicals such as DDT and dioxin and the setting aside of millions of acres of ecologically-sensitive public land and marine areas for protection.

Although the accomplishments are numerous, environmental challenges remain. Most notably, there is the problem of climate change. At the federal level, the U.S. Congress has failed to enact meaningful legislation to require sources of greenhouse gases to reduce their emissions. For its part, the EPA began the process of using its CAA authority to mandate such emissions reductions, but regulatory approaches crafted during the Obama Administration that targeted fossil fueled power plants and cars and trucks were reversed by the Trump Administration (Konisky and Woods 2016). States, and to some degree local governments, have attempted to fill the void at the federal level through their own policies, such as renewable energy mandates and cap and trade programs (Carley 2011; Rabe 2004, 2011; Raymond 2016), with some success. However, there also remain many state laggards that have been unwilling to hasten a transition to cleaner sources of energy, and in many states, there has been policy retrenchment that has curtailed the limited progress toward deploying cleaner, renewable energy technologies (Stokes 2020). Moreover, the progress that has been made due to policies, changing market conditions, and technological innovations, has to date mostly led to reduced emissions in the electric power sector, while much less progress has been made in the areas of transportation, agriculture, and the built environment.

Beyond climate change, progress has also been slow in other areas. Despite some improvements, many of America's rivers, lakes and other surface waters remain impaired. In addition, recent assessments of benefits and costs have raised questions about the return on investment of water quality policy interventions (Keiser and Shapiro 2018), though measuring benefits is a difficult challenge (Keiser, Kling, and Shapiro 2019). A key reason for persistent water quality problems is that the CWA only targets point sources of pollution (e.g., factories and wastewater treatment plants that discharge pollution directly into a waterway), leaving virtually unregulated important nonpoint sources of water pollution such as fertilizer and pesticide runoff from agriculture. One obvious consequence of this regulatory gap in the CWA is annual algae blooms that arise in the Gulf of Mexico, and, in recent years, in places like Lake Erie (in 2014, the City of Toledo shut off drinking water to its 400,000 residents as a result). The lead water crisis in Flint Michigan also illustrates that water quality problems still exist in the U.S. drinking water system. The Flint crisis itself was more a failure of policy implementation than policy design; in this case, the problem was not lack of technology or policy authority, but the flawed decision-making and knowing neglect of government officials that resulted in the endangerment of a poor, disenfranchised, community of color (Pauli 2019).

The Flint water crisis also highlights another enduring dimension of U.S. environmental policy, which is that communities of color and low income often experience a disproportionate share of the remaining pollution burdens. Decades of social science research on "environmental justice" has documented race- and income-based disparities in the location of hazardous waste landfills and incinerators, contaminated sites such as those being remediated as part of the federal Superfund program, Toxics Release Inventory facilities, and other sources of environmental risks (Brulle and Pellow 2006; Ringquist 2005). The causal mechanisms 
underlying these patterns are quite challenging to disentangle analytically (Banzhaf, Ma, and Timmins 2019), but there is little dispute about their existence. A grassroots movement for environmental justice emerged in the early 1980s (Bullard 1993; Cole and Foster 2001; Taylor 2000), and, in part led by scholar-activists, successfully forced equity issues on to the agenda. However, to date, the government response at the federal level has been limited and largely ineffective (Harrison 2019; Konisky 2015), and state policy action has been inconsistent and mostly symbolic (Abel, Salazar, and Robert 2015; Ringquist and Clark 1999). The emergence of the environmental justice movement, as well as the sustained involvement of environmental organizations (Bosso 2005), illustrate that concerns about the environment, 50 years after the first Earth Day, continue to animate mobilization in civil society.

Climate change, nonpoint source pollution, disparities in environmental harms, and other unmet challenges are difficult to address, although perhaps less from a technical standpoint than from a political one. In fact, arguably the biggest hurdle inhibiting further progress on environmental problems is politics. Environmental policy has not been immune from broader developments in the American political system that have prevented meaningful and sustained policy attention. Whereas both major political parties competed for environmental voters at the onset of the modern environmental era, environmental protection is now perceived as an issue "owned" by the Democratic Party (Egan 2013). This issue ownership is also reflected in the severe partisan polarization that now exists, at both the elite (Jeong and Lowry 2019; Kim and Urpelainen 2017; Shipan and Lowry 2001) and mass public level (Egan and Mullin 2017). Partisan polarization has contributed to gridlock in Congress, which has resulted in a prolonged period of legislative inactivity on environmental issues (Klyza and Sousa 2013). With just a couple of exceptions (e.g., the 1996 Food Quality Protection Act, the 2016 Toxic Substances Control Act), Congress has not enacted major pollution control legislation since the 1990 Clean Air Act Amendments. One important consequence is that government agencies are generally stuck with the policy tools given to them five decades ago, limiting the opportunities to employ potentially more effective and efficient alternatives.

With Congress willing neither to improve the effectiveness of existing legislation nor to create new policy authorities to address emergent problems such as climate change, presidents have turned to tools of the administrative presidency. Depending on their policy objectives, Republican and Democratic presidents alike have used executive orders, administrative reorganization, and rulemaking to either strengthen or loosen environmental protections. There are a number of consequences of this mode of environmental policymaking. First, policy in recent decades has zig-zagged, with increasingly large swings from one presidential administration to the next (Konisky and Woods 2018). Legislative interpretations and rulemakings by one president have regularly been reinterpreted or replaced by a subsequent president with conflicting preferences. Second, the reliance on administrative tools has even further heightened the intensity of interest group activity, in a way characteristic of the special interest warfare that Lowi (1972) describes as capturing regulatory policy. Relatedly, because most administrative action is eventually litigated, increased regulatory activity amplifies the importance of the federal courts, further raising the stakes of judicial selection. In all of these ways, the same forces that shape American politics generally, have become part and parcel of contemporary U.S. environmental policy. 


\section{SCHOLARLY LITERATURE}

Given the immense challenges that remain and the contentious politics that permeate nearly all dimensions of U.S. environmental policy, it is an important moment to take stock of the scholarly literature. To be clear, academic researchers have for many decades deeply explored the policy options, governance strategies, efficiency and equity features, political, economic, social, and cultural intersections, and philosophical dimensions of U.S. environmental policy. The literature is extensive. Scholars from wide-ranging disciplines, including economics, geography, history, law, political science, psychology, and sociology, have comprehensively analyzed the environmental decisions, behaviors, and perceptions of government agencies, private sector firms, and individuals. Researchers have pursued questions from both a normative and positive perspective, using diverse methodological approaches. Empirical research is increasingly sophisticated, relying both on carefully executed qualitative approaches and state-of-the-art econometric methods that provide researchers with analytical leverage to make causal inferences.

The primary objective of this book is to provide an overview of key research in diverse areas of inquiry with respect to environmental policy. The short chapters are not intended to be exhaustive reviews of the literature, but rather to synthesize important scholarship and to provide an intellectual launching pad for researchers interesting in pursuing their own research. In each chapter, the authors describe and analyze ideas and theoretical frameworks, empirical findings, and methodological approaches to understanding the principal research questions driving researchers in the field. Authors also emphasize areas of emerging research and highlight opportunities for new work.

The chapters in the Handbook focus almost exclusively on the United States. Of course, the United States is not unique in the environmental problems its citizens face, and challenges such as climate change obviously expand beyond the borders of any one nation. Further, scholarship on environmental policy has demonstrated the tremendous value of a comparative approach to help illuminate the role of political and legal institutions, economic systems, civil society, and social and cultural norms. In addition, other work emphasizes the important role of the United States as an actor in international politics and policymaking. Other Handbooks focus on these dimensions (e.g., Dauvergne 2012) and this volume begins from a position that there is plenty to learn and understand from the U.S. case.

\section{OVERVIEW OF THE BOOK}

The book is organized into five key parts. The chapters in the first part, Political Institutions, discuss the interplay of environmental policy and American political institutions, covering the presidency, Congress, bureaucracy - separately from the vantage point of the EPA and the Department of Interior - the courts, federalism and the states, and local governments. Each of these institutions is important for understanding U.S. environmental policy, and each has received considerable attention from scholars across social science disciplines. Of course, these political institutions interact in a complicated web of policymaking and implementation, in ways that the authors also discuss.

In the next part of the book, Politics and Behavior, the authors examine the role of issues, political organizations, and the mass public in US environmental policy. The chapters in this 
part of the book review scholarship on agenda-setting, specifically how political actors attempt to move environmental issues onto the agenda of government (or in some instances, keep issues off the agenda), as well as the role that environmental issues have in voting behavior and electoral politics. In addition, other contributions to this section of the Handbook provide overviews of the current state of knowledge regarding the priorities and strategies of organized political interests, including both organizations that advocate for environmental protection and organizations that try to impede such efforts. Finally, chapters in this section review scholarship on how the public participates in environmental policy through expression of opinion and through more direct engagement.

The third part of the book, Policy Tools and Strategies, turns to important questions about policy tools. The modern environmental policy era in the United States - which began with the establishment of the EPA in 1970 and the large portfolio of statutes that Congress enacted during the "environmental decade" of the 1970s - relied primarily on command-and-control style regulations. This prescriptive approach to policy has been the bedrock of U.S. environmental policy for decades, and it remains the dominant approach, but is also often criticized as inefficient, inflexible, and ineffective in spurring innovation. Efforts to use markets, performance-based standards, information provision, industry self-regulation, and collaborative approaches have each been proposed as complements, or in some cases, substitutes to regulation. In many respects, the scholarly community has been instrumental in helping policymakers understand the opportunities and challenges of these alternative strategies, and the authors of the chapters highlight what we know about their successes and limitations.

The fourth part, Climate Change, focuses on what is undoubtedly the key challenge of our time. Climate change, of course, is not just an environmental problem, but it has been framed that way in the United States from its emergence on the national agenda (as opposed to a problem of energy, economy, or national security). Just as climate change has come to dominate public discourse on the environment, research on climate change in the United States has accelerated in recent decades. In this section, authors contribute chapters that cover the evolution of policymaking at multiple levels of government, U.S. engagement in international policy and politics, and the communication and advocacy strategies of both environmental organizations interested in pushing for more aggressive action to address the problem, and business and other individuals and organizations that seek to indefinitely delay policy action and sow denial about the very reality of the problem. Finally, chapters in this section provide overviews of social science research in the areas of climate adaptation and climate engineering, each of which has emerged in recent years in response to a growing realization that the slow pace of mitigation means that other strategies will be necessary.

In the final part of the book, Ideas and Challenges, the authors focus on a set of key ideas and frameworks that garner considerable attention from environmental policy scholars. Alongside the theoretical and empirical scholarship that has characterized much of the environmental policy field in recent decades, there has also been important normative work in political theory and ethics and on the intersection of environmental policymaking and deliberative democracy. This section of the book also reviews recent work that examines the role of distributive, procedural, and other forms of justice in the fields of environment and energy. Lastly, the final two chapters of the book review interrelated literatures on corporate social responsibility and sustainability, with each chapter discussing key definitional questions as well as appraising the state of knowledge about the adoption of socially responsible and sustainable practices within private sector firms and local government agencies. 
The chapters to follow provide a starting point for scholars interested in beginning their own research on a diverse set of subjects important in the field of U.S. environmental policy. There are no shortages of questions, and there remains ample opportunity for innovations in theory, data, and methodology. Given the urgency and complexity of problems like climate change, scholars have much to contribute.

\section{REFERENCES}

Abel, T. D., D. J. Salazar, and P. Robert (2015), 'States of environmental justice: Redistributive politics across the United States, 1993-2004', Review of Policy Research, 32 (2), 200-225.

Andrews, Richard N. L. (1999), Managing the Environment, Managing Ourselves: A History of American Environmental Policy, New Haven, CT: Yale University Press.

Banzhaf, S., L. Ma, and C. Timmins (2019), 'Environmental justice: The economics of race, place, and pollution', Journal of Economic Perspectives, 33 (1), 185-208.

Bosso, Christopher John (2005), Environment, Inc.: From Grassroots to Beltway, Lawrence, KS: University Press of Kansas.

Brulle, R. J. and D. N. Pellow (2006), 'Environmental justice: Human health and environmental inequalities', Annual Review of Public Health, 27, 103-124.

Bullard, Robert D. (ed.) (1993), Confronting Environmental Racism: Voices from the Grassroots, Boston, MA: South End Press.

Carley, S. (2011), 'The era of state energy policy innovation: A review of policy instruments', Review of Policy Research, 28 (3), 265-294.

Carlson, Ann and Dallas Burtraw (eds.) (2019), Lessons from the Clean Air Act: Building Durability and Adaptability into US Climate and Energy Policy, New York, NY: Cambridge University Press.

Cawley, R. M. (1993), Federal Land, Western Anger: The Sagebrush Rebellion and Environmental Politics, Lawrence, KS: University Press of Kansas.

Cole, Luke W. and Sheila R. Foster (2001), From the Ground Up: Environmental Racism and the Rise of the Environmental Justice Movement, New York, NY: NYU Press.

Culhane, Paul J. (1981), Public Lands Politics: Interest Group Influence on the Forest Service and the Bureau of Land Management, New York, NY: RFF Press.

Dauvergne, Peter (ed.) (2012), Handbook of Global Environmental Politics, Cheltenham, UK and Northampton, MA, U.S.A.: Edward Elgar Publishing.

Davies III, J. Clarence (1970), The Politics of Pollution, New York, NY: Pegasus.

Davis, Charles (2001), Western Public Lands and Environmental Politics, 2nd Edition, Boulder, CO: Westview Press.

Doyle, Martin (2018), The Source: How Rivers Made America and America Remade its Rivers, New York: W. W. Norton.

Egan, Patrick J. (2013), Partisan Priorities: How Issue Ownership Drives and Distorts American Politics, New York, NY: Cambridge University Press.

Egan, P. J. and M. Mullin (2017), 'Climate change: US public opinion', Annual Review of Political Science, 20, 209-227.

Harrison, J. L. (2019), From the Inside Out: The Fight for Environmental Justice with Government Agencies, Cambridge, MA: MIT Press.

Jeong, G. and W. Lowry (2019), 'The polarisation of energy policy in the US Congress', Journal of Public Policy (published online).

Keiser, D. A. and J. S. Shapiro (2018), 'Consequences of the Clean Water Act and the demand for water quality', The Quarterly Journal of Economics, 134 (1), 349-396.

Keiser, D. A., C. L. Kling, and J. S. Shapiro (2019), 'The low but uncertain measured benefits of US water quality policy', Proceedings of the National Academy of Sciences, 116 (12), 5262-5269.

Kim, S. E. and J. Urpelainen (2017), 'The polarization of American environmental policy: A regression discontinuity analysis of Senate and House votes, 1971-2013', Review of Policy Research, 34 (4), 456-484. 
Kline, Benjamin (2011), First Along the River: A Brief History of the U.S. Environmental Movement, Lanham, MD: Rowan \& Littlefield.

Klyza, Christopher McGrory and David J. Sousa (2013), American Environmental Policy: Beyond Gridlock, Updated and Expanded Edition, Cambridge, MA: MIT Press.

Konisky, David M. (ed.) (2015), Failed Promises: Evaluating the Federal Government's Response to Environmental Justice, Cambridge, MA: MIT Press.

Konisky, D. M. and N. D. Woods (2016), 'Environmental policy, federalism, and the Obama presidency', Publius: The Journal of Federalism, 46 (3), 366-391.

Konisky, D. M. and N. D. Woods (2018), 'Environmental federalism and the Trump presidency: A preliminary assessment', Publius: The Journal of Federalism, 48 (3), 345-371.

Lowi, T. J. (1972), 'Four systems of policy, politics, and choice', Public Administration Review, 32(4), 298-310.

McCarthy, G. and T. A. Burke (2017), 'We need a strong Environmental Protection Agency: It's about public health!', American Journal of Public Health, 107 (5), 649-651.

Pauli, Benjamin J. (2019), Flint Fights Back: Environmental Justice and Democracy in the Flint Water Crisis, Cambridge, MA: MIT Press.

Rabe, B. (2011), 'Contested federalism and American climate policy', Publius: The Journal of Federalism, 41 (3), 494-521.

Rabe, Barry G. (2004), Statehouse and Greenhouse: The Emerging Politics of American Climate Change Policy, Washington, DC: Brookings Institution Press.

Raymond, Leigh (2016), Reclaiming the Atmospheric Commons: The Regional Greenhouse Gas Initiative and a New Model of Emissions Trading, Cambridge, MA: MIT Press.

Ringquist, E. J. (2005), 'Assessing evidence of environmental inequities: A meta-analysis', Journal of Policy Analysis and Management, 24 (2), 223-247.

Ringquist, E. J. and D. H. Clark (1999), 'Local risks, states' rights, and federal mandates: Remedying environmental inequities in the US federal system', Publius: The Journal of Federalism, 29(2), 73-94.

Shipan, C. R. and W. R. Lowry (2001), 'Environmental policy and party divergence in Congress', Political Research Quarterly, 54 (2), 245-263.

Stokes, Leah C. (2020), Short Circuiting Policy: Interest Groups and the Battle Over Clean Energy and Climate Policy in the American States, New York: Oxford University Press.

Taylor, D. E. (2000), 'The rise of the environmental justice paradigm: Injustice framing and the social construction of environmental discourses', American Behavioral Scientist, 43 (4), 508-580.

U.S. Environmental Protection Agency (EPA) (1997), The Benefits and Costs of the Clean Air Act, 1970 to 1990, Washington, DC.

Vincent, Carol Hardy, Laura A. Hanson, and Carla N. Argueta (2017), Federal Land Ownership: Overview and Data, Congressional Research Service, March 3.

Wang, G. A. (2018), 'Who controls the land? Lessons from armed takeover of the Malheur national wildlife refuge', Case Studies in the Environment, 2 (1), 1-6. DOI: https://doi.org/10.1525/cse.2017 .000778 .

Wertz, Wendy Read (2014), Lynton Keith Caldwell: An Environmental Visionary and the National Environmental Policy Act, Bloomington, IN: Indiana University Press.

Williams, Dennis C. (1993), The Guardian: EPA's Formative Years, 1970-1973, Washington, DC: Environmental Protection Agency. 